\title{
Model Of Implementation Of Family Planning Program In The Era Of Democracy Through The Improvement Of Participation Of People In East Java
}

\author{
Dr. Dewi Amartani, M.SI*, Prof. Dr. Tatiek Sri Djatmiati, S.H., M.S \\ Akhmad Fauzie, S.PSI., M.PSI \\ *Bhayangkara University Surabaya,-Indonesia
}

\begin{abstract}
The problem of population is not just a problem of the nation with the highly densed population, but it is also an issue of the world. If the growth of population in a country is not well controlled, it will also have an impact on other countries since it is closely related to the such as common global problems of food, health and natural resources. Considering the above description, it is highly recommended that all parties coopeate and work synergically. It must be managed locally, nationally and internationally. The population of Indonesia was ranked the fourth in the world. During the reign of the last authoritarian, the the family planning program gained its great success since its policy was based on power and force. Now in the era of a democratic political system, it is necessary to create such participative patterns to educate the people by involving all government and private agencies, and non-governmental organizations.
\end{abstract}

Keywords: Model, Family Planning, Participation, Policy

\section{Background}

The four most populous countries in the world are China, India, United States, and Indonesia. Sooner or later Indonesia will experience food security crisis. (http://id.berita.yahoo.com/empat-state). Based on the census conducted at the beginning of the year 2010, the population of Indonesia is 237,556,363 (www.google.co.id/publicdata). The rate of its growth from 2000 to 2010 increased from $1.45 \%$ to $1.49 \%$. (http://health.detik.com/read/2012).

Indonesia gained its great success of the Family Planning (FP) in the era of the new order in the yeras of 1994-1995, when the authoritarian government was still run perpetually. In the period of the democracy today, the population with FP cannot be handled and managed effectively. It results in poverty and unemployment as well as health and environmental problems. The highly densed population will add to the burden and hinder the nation to move forward. To improve the quality of Human Resources (HR) in the future, and to accelerate the reduction of the poverty, it is absolutely obliged to locate the planning program as the priority. (Http://kaltim.bkkbn.go.id/Lists/Artikel) It requires several strategic studies to revitalize the family planning programs. It is urgent to conduct a research with its aim to design a model of the implementation of the family planning programs in accordance with the circumstances and conditions of the democratic political system which requires the participation of all parties. (Lismomon Nata, http://sumbar.bkkbn.go.id)

The role of government institutions/bureaucracy, social and economic organizations and institutions is very important to manage the problems in the political transition period in boosting the effectiveness and the efficiency of the family planning programs. That is why it is necessary to design appropriate model to implement the family planning programs in the era of democracy through the improvement of the citizen participation.

\section{Library Studies}

Family Planning (FP) is a program that works for couples to postpone the birth of the first child (post poning), to have a child spacing (spacing) or to limit (limiting) the desired number of children in accordance with the medical safety and the possible return of fertility phase (ferundity). The Family Planning Program aims to meet the demand for the qulified services of the family planning and the reproductive health as well as the rate of the birth control so that in turn it will lead to the improvement of the quality of the population and the realization of small, qualified families. One of the strategies in the implementation of the public policy is the partnership approach between the government and the society.(http: /psikis.bkkbn.go.id/gemapria/articles.php). The research of (Nunung Nurwati, 2006: 70) the multidimensional crisis in Indonesia prolonged the impact of the economic pressures affecting the society, especially the lower classes. It resulted in the decrease of the capability of these groups to access and use the tools of contraception, and examination. (Sarwirini 2011: 52). It 
is necessary to synergize all legislative and executive parties to build the networks of cooperation for both the government and the private parties, to empower the families based on the local culture.

The participation of the community can be considered as the participation of all parties in supporting the implementation of the family planning programs including the parties of the business sector. The empowerment is referred to the capability of the people, especially the vulnerable and weak ones, to have an access to the productive resources and participate in the process of the development.

Communication is the main key in improving the participation of the people as to achieve a harmonious family life there many factors to consider. (Sukmana, 2006) (1) The role of each member of the family, (2) empathy (putting yourself in someone else), (3) Life Experiences, (4) Customs, (5.) The purpose of the family, (6) Family Budget, (7). Relations (communication). In the era of democracy, the patterns of the communication of the family planning programs must be adjusted with the social, economic and political changes. The communication between the FP cadres and the targeted persons requires some improvemnets to succeed the family planning program. So far the program is only focused on the mothers although the fathers are also the targets of the program. Additionally, there are many rumors in the society because the quality of the information is very bad.

The implementation of the FP experienced some barriers associated with a variety of issues: (http://www.menkokesra.go.id). First, the existence of some cultural barriers. The condition is associated with a "value of children" adopted by society nowadays. The motto is "many children, many fortunes". Second, the work ethic, bureaucracy and all elements of the society. Third, the synchronization of policy between the central and regional government. Fourth, the legislation with the issuance of Act No. 52 of 2009 on the Development of the Population and of the Family, but after over three years of the promulgation, it has not been followed by some government regulations as the implementation of the family planning policy

\section{Research Method}

The purpose of the research was to find out a Model or Draft of the Implementation of Family Planning Program in the Era of Democracy through the Improvement of the Participation of the people in East Java. The qualitative approach was applied in the study to analyze the problems. By implementing the approach, it was expected to have such comprehensive and holistic studies towards the problems and to deepened them through various disciplines including Public Administration, Administrative Law and Psychology. The location of the study was in East Java and the regency of Ngawi was purposively selected as the research area. The data also including the secondary ones were collected by interviews and focus group discussions.

\section{Policy of Family planning in East Java}

\section{Results And Discussion}

The family planning program in Indonesia as a population policy was quite successful in the reign of the previous authoritarian. These policies become stagnation when there was a change in Indonesian politics which led to the democratic process. When the democratic process was getting stable, the people began to realize that the Indonesia's population at the time was the world's fourth largest. Then the government and the people thought that there had to be some necessities to revitalize the family planning program to controll the rate of the growth of the population. In the democratic era some regulations as the legal basis of any government policies were necessary to revitalize the family planning program.

It is stated in the Act of the Republic of Indonesia No. 52 of 2009 on the Development of the Population and Family that in achieving a balanced population growth and qualied families various efforts must be taken, namely: birth control, reduction in mortality, population mobility guidance, quality development of the population in their entire dimensions, improvement of the resilience and welfare of the families, and preparation and arrangement of marriage and pregnancy. Improving the quality of the human resources was placed at its main focus rather just creating a balance which was calculated quantitatively.

Based on some information written in the book titled: Grand Design of the Quantity Control of Population in East Java Province (No Name, 2012: 8-20) it can be determined that the policy of the family planning in East Java has three quantitative, main objectives including: fertility, mortality, and population distribution. The current program of the family planning is expected to shift the paradigm that puts the prioity in the pattern of development pertaining to the population/demography. Such a development contains two meanings, the first: the development appropriate with the potential/potency and conditions of the existing people; second: human resource development, that is the development which emphasizes on the quality of human resources rather than the infrastructure improvements alone. In the future the planning and implementation of the development can no longer ignore the role of the people as an object or a subject or agent of development. 
Variables Influencing the Effectiveness of the Implementation of Family Planning in Democratic System The policy of the family planning in Indonesia experienced its ups and downs because of the political changes from authoritarian to democratic politics. It led to its implementation. It suffered from a setback since the previous authoritarian operated its Top Down policy and force. In the era of democracy, the success of famaly planning were determined by the following variables:

1) Institution. In the era of democracy and as a consequence of the autonomous system in the regions, there had been a stagnated period because each region had its own policy and the central government could not intervene in the policies concerning the population. Now the institutions were rearranged although the realities were not as they were expected, but at least there was some attention from the government and the people. They realized the importance of the revitalization on the implementation of the family planning so that it could be effective again.

2) Law. As a democratic nation, each policy had to be based on a clear legal basis. It was important primarily associated with the relationship of the central and local governments and the people relating to the rights and obligations of the people who want to be involved in the family planning programs.

3) Human Resources. As a consequence of political changes, the Human Resources (HR) became a serious problem, especially in the areas experiencing the shortages due to the downsizing or structural mutations, both promotion and transfer of duties. The central government proposed an additional of 3,000 field workers of the family planning to anticipate the lack of field officers .

4) Ideology of Society. The success of the family planning in Indonesia could not be separated from the significant role of the religious leaders and communities who approached the people rejecting the programs of the family planning, especially the lower layers of the society. The middle class group tended to maintain their ideology so that there was a tendancy that they had more than two children and some have absolutely no limit on the number of children. Some education for the lower society was extremely needed and could be done by the religious figures. Now they have just lesser role and due to the economic conditions, the importance of family planning was acceptable.

5) Socioeconomic society. The bottom layer society is less likely to have the capability to plan the lives of their families because most of them were still thinking of how to make a living and psychologically they just submitted their fate to the circumstances so that they had less motivation to strive to make the amilies more prosperous $\mathrm{f}$.

6) Affordability of services. The affordability of services was one of the important keys to support the effectiveness of the implementation of family planning policies; Good service would encourage the participation of the community to participate in the family planning programs. Services included not only the physical facilities but also the readiness of the human resources. They were the key factor in determining the quality of service; for the poor families were not charged and they would be led to have their economic empowerment.

7) Cadres. In the era of democracy, the participation of the people in the family planning program appeared in the form of community called cadres, for example: community development groups for toddler families, youth, and groups of economic activities. The participants were not only from the family planning participants but also from all elements of government agencies and private companies which was called the partnership network.

8) Information Technology. Advances in technology put to good use to support the family planning programs. It was used to facilitate some accesses to all kinds of information and also to provide educational media which could go through the boundaries of all layers, regions and time.

9) Mass Media. In the democratic era mass media are getting more important to improve the access to information for the community, and vice versa, the media can provide, control, education and motivation for the community. They offer more various types of activities of mass media. They can do the agenda setting to increase the public awareness on population issues.

\section{Draft Model}

Based on the various analysis mentioned earlier, the design of the model of the implementation of the family planning programs in the era of democracy through the participation of the people is described as follows: 


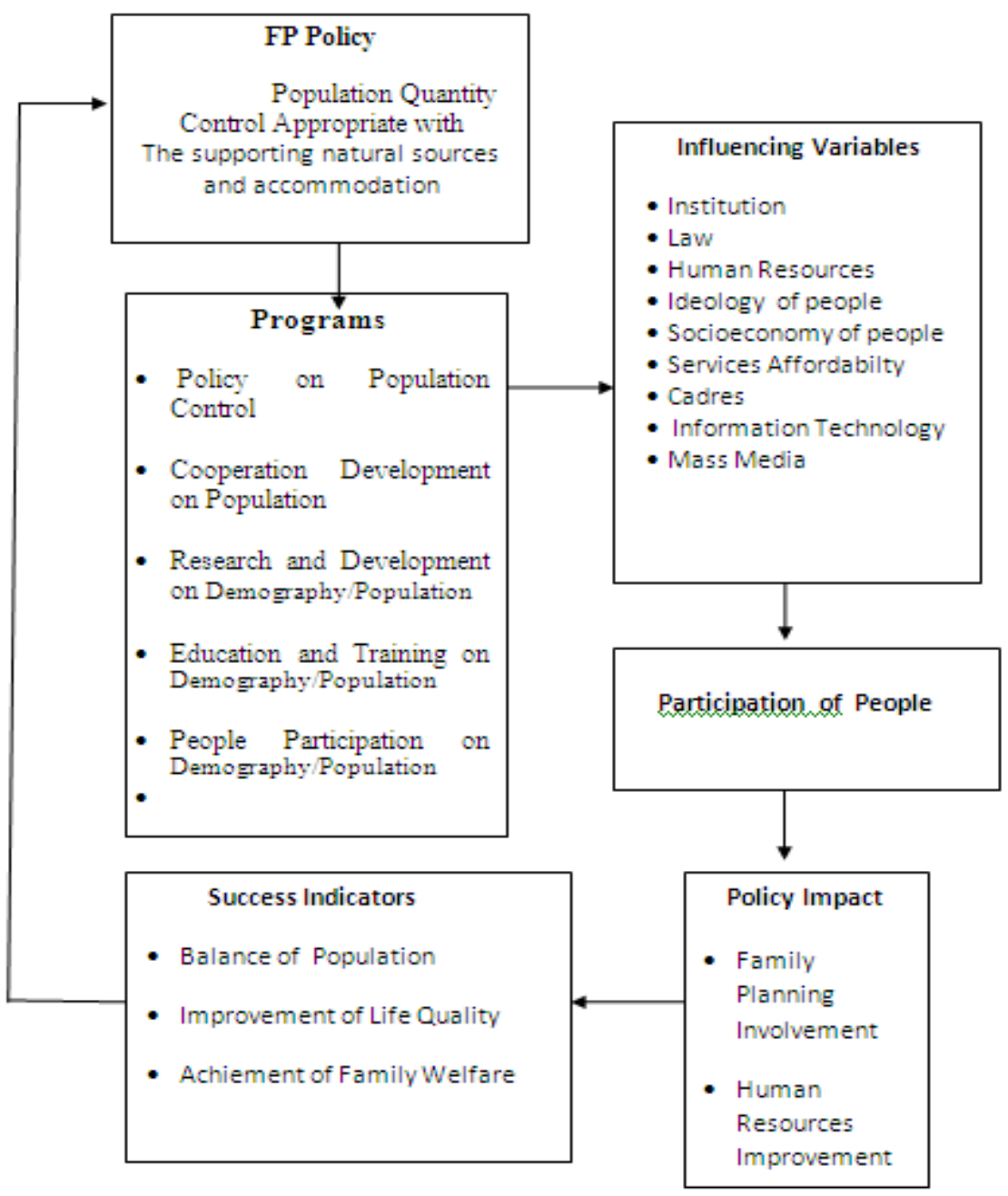

\section{Conclusion}

At the time of the democratic era there had been some changes in the policies. During the authoritarian period there were greater emphasis on controlling the quantity by applying the mobilization patterns. On the other hand, in the democratic era, the greater emphasis were focused on the balance of the supporting capacity of the environment, the human resources, the participatory approaches and partnerships. During the authoritarian, the family planning policies were based on the power of government, but nowadays in the democratic government they are based on the rules of law which make the central and regional government and the community work together to improve the effectiveness of the implementation of family planning policy. In a democratic political system it is necessary to provide varied education patterns for the people by involving all government and private agencies, and non-governmental organizations. The implementation of the family planning would be effective when the public access was enhanced. The improvement of the quality of the human resources in the government and society, the economy and the importance of local, national and international partnerships should be highly considered because the population problem cannot be addressed without actively involving all parties.

\section{Suggestion}

Under the legal protection in the forms of the acts, it is necessary to have some regulations so that they can be technically implemented as a reference by both central and local governments. The population problem is not just a problem of a nation with the high population, but it is also an issue of the all people in the world. If the growth rate of the population is not controlled in a country, it will also have an impact on other countries, and it results in the problems of food, health and natural resources. So that it is necessary to work together locally, nationally and internationally and have the synergy of the related activites of all parties. 


\section{Bibliography}

[1]. No Name, 2012, Grand Desain Pengendalian Kuantitas Penduduk di Propinsi Jawa Timur, KERJASAMA PERWAKILAN BKKBN PROVINSI JAWA TIMUR DENGAN KOALISI KEPENDUDUKAN PROVINSI JAWA TIMUR TAHUN 2012

[2]. Etna Estelita, LSM De Mande Keluarga Berencana Dan Indekspembangunan Manusia http://Sumbar.Bkkbn.Go.Id/Lists/Artikel/ Dispform.Aspx?Id=33\&Contenttypeid=0x01003dcababc04b7084595da364423de7897 Dikutip 5 Agustus 2012

[3]. LismomonNata,http://sumbar.bkkbn.go.id/Lists/Artikel/DispForm.aspx?ID=37\&ContentTypeId=0x01003DCABABC04B7084595 DA364423DE7897, Dikutip 9 Agustus 2012

[4]. Sukmana, 2006, Lingkungan Keluarga Harmonis Sejahtera Menuju Keluarga Berkualitas 2015, Jurnal Lingkungan Keluarga Edisi kedua Tahun III, 2006

[5]. Sarwirini, Rancangan Model Pemberdayaan Keluarga Untuk Mencegah Terjadinya Tindak Kekerasan Dalam Rumah Tangga (Kdrt) Di Jawa Timur

[6]. http:/psikis.bkkbn.go.id/gemapria/articles.php

[7]. http://pkbi.or.id/, RENSTRA PKBI (Perkumpulan Keluarga Berencana Indonesia 2010-2020

[8]. http://health.detik.com/read/2012/07/31/122228/1979228/763/apakah-program-kb-berhasil-bkkbn-tunggu-hasil-survei-2012

[9]. http://kaltim.bkkbn.go.id/Lists/Artikel/DispForm.aspx?ID=136\&ContentTypeId=0x01003DCABABC04B7084595DA364423DE78 97, dikutip 7 Agustus 2012

[10]. http://www.menkokesra.go.id. 